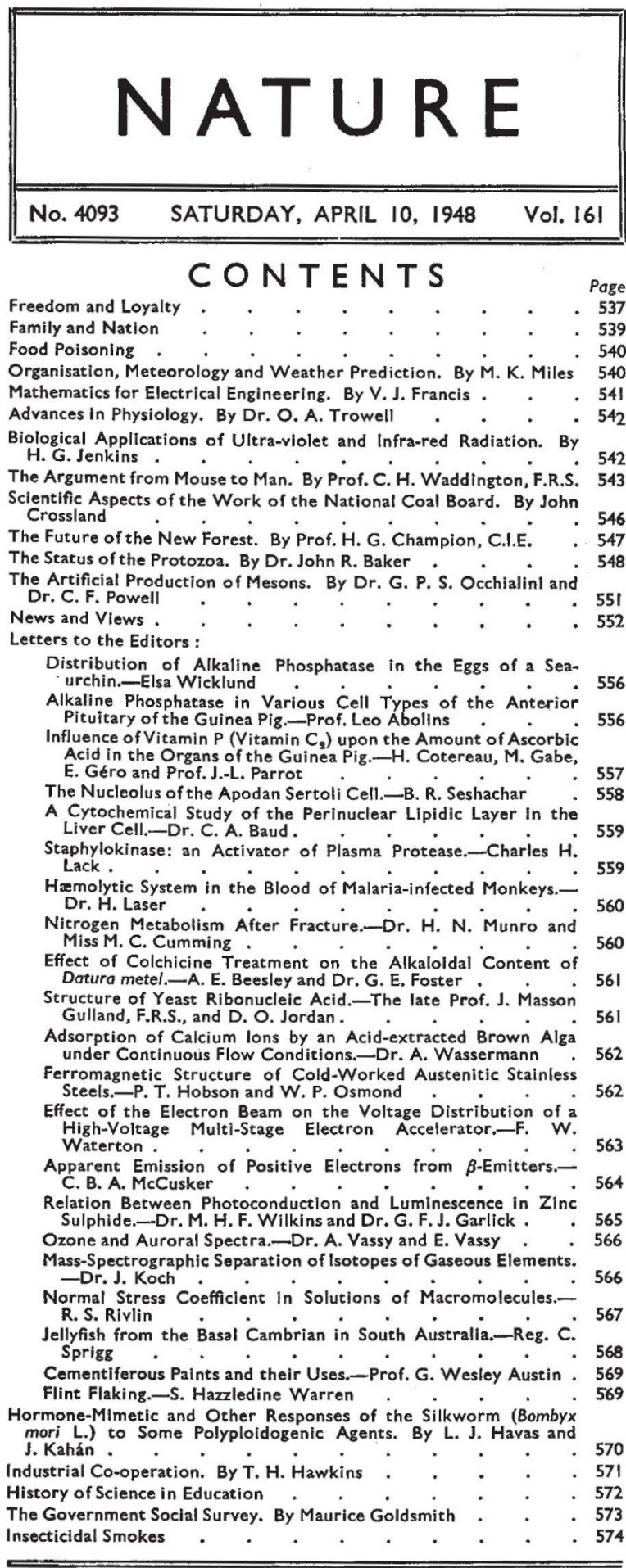

Editorial and Publishing Offices

MACMILLAN \& CO., LTD.,

ST. MARTIN'S STREET, LONDON, W.C.2.

Telephone Number: Whitehall 883 !

Telegrams : Phusis Lesquare London

Advertisements should be addressed to

T. G. Scott \& Son, Ltd., Talbot House, 9 Arundel Street, London, W.C.2 Telephone: Temple Bar 1942

The annual subscription rate is $£ 4100$, payable in advance, Inland or Abroad All rights reserved. Registered as a Newspaper at the General Post Office

\section{FREEDOM AND LOYALTY}

IN the course of his inspiring address on "The Iscientist in Industry" to the Federation of British Industries at a meeting held at the Royal Institution on March 19 in honour of him and Sir Robert Robinson as Nobel Prize winners in 1947, Sir Edward Appleton referred to the vital importance of avoiding any segregation or isolation of research effort. He spoke also of the need for interpreting as liberally as possible whatever restrictions may have to be imposed in the interests of Government departments or industrial firms on men of science serving such organisations. Sir Edward's address was pervaded with a lively sense of the value of human factors; and above all of the importance of freedom of intercourse and movement; his words, indeed, contrast strongly with the restrictions which the Government announced a few days earlier on the employment of members of Communist and Fascist organisations in the service of the State. On grounds of national security, the Government has concluded that the only prudent course to adopt is to ensure that no one who is known to be a member of the Communist Party, or to be associated with it in such a way as to raise legitimate doubts about his or her reliability, is employed in connexion with work the nature of which is vital to the security of the State.

No reasonable exception can be taken to the terms of the Prime Minister's statement. The State, he said, is not concerned with the political views as such of its servants, and so far as possible alternative employment on the wide range of non-secret Government work will be found for those who are deemed to be unsuitable for secret work. Experience both in Great Britain and elsewhere has shown that membership of, and other forms of continuing association with, the Communist Party, may involve the acceptance by the individual of a loyalty which in certain circumstances can be inimical to the State.

However regrettable this decision may be and there are consequences that involve some further consideration-no Government could pretend that there are not certain duties of such secrecy that the State ought not to employ in connexion with them anyone whose political discretion is in doubt. It shows a misconception of the Prime Minister's statement and purpose to urge that such action should only be taken after the individual concerned had had opportunity of appeal to some form of tribunal, or after weighing evidence by a judicial process. The point is that there is no specific charge brought against the individuals affected. As Mr. Attlee said, it is not suggested that in matters affecting the security of the State all Civil servants who adhere to the Communist Party would allow themselves to forget their primary loyalty to the State; but there is no way of distinguishing such people from those who might endanger the security of the State.

The Government in this precautionary measure has manifestly stopped well short of the point at which liberty and conscience are imperilled or economic sanctions raised against particular political creeds. Western democracy works by toleration and 
governs by consent, and the Government's moderation is in startling contrast to the methods pursued by Eastern communism--its rigid intolerance, intransigence and persistent attempts to over-run the frontiers of sincere democratic patriotism, and to crush freedom wherever it exists. To survey the plight of freedom in the satellite countries of the U.S.S.R. is to realize the enormous contrast, and also the moderation and realism of the British Government's action.

The University of Prague, which has been celebrating its sixth centenary, provides a case in point. In view of their information that for the time being the Charles IV University is subject to Government controls which deny to it the academic autonomy essential to all free and responsible university work, the universities of Great Britain reluctantly decided that their official representation at the celebrations would be inappropriate. Every university felt itself honoured by the invitation to Prague, and desired to pay tribute to the high and historic service of the Charles IV University to scholarship and science, and to the making of our common heritage of truth and freedom; but Sir Hector Hetherington, acting chairman of the Committee of Vice-Chancellors, has stated in The Times that it has seemed necessary to the universities to give no ground for the opinion that British universities are favourable to the changes wrought in the universities of Czechoslovakia.

That action, moreover, illustrates further a point made in a recent article in The Economist. There is urgent need, it was argued, for an effective counterattack on communist activities and propaganda in all walks of life, in public affairs, in science particularly, and above all in the factories. Recent events have made a little plainer whither divided loyalties may lead us; but if the free nations are to preserve their liberties and their great traditions, they cannot continue to tolerate intolerance. They must, it is true, work out their own means of self-protection by their own democratic method; but they must not allow themselves to be deceived by the professions of those who reject these methods and only use them to subserve their purpose of intolerance and disruption.

In contrasting Sir Edward Appleton's words with the new policy, it should have been noted that in his plea for freedom he stressed the discipline of science. That should be the first loyalty of the man of science; and it is because that discipline and loyalty are rejected by the communist that science itself is endangered by communism as we know it in Soviet Russia. The totalitarian regime is inconsistent with the free pursuit of science, and professional workers would do well to address themselves more carefully to this question of professional loyalty. Without loyalty to the highest professional ideals and traditions, inherent in which is the tradition of faithful service to the society for whose welfare a profession exists, the pursuit of truth and the advancement of learning cannot long endure.

In this connexion Mr. Middleton Murry has a significant passage in his recent book "The Free
Society"*. $\mathrm{He}$ is convinced that the contemporary confidence in the autonomy and invulnerability of science has no solid foundation. Science, he holds, is as vulnerable as the free society and is ultimately dependent on it. "The matrix of science has been the politically free society, first in Greece, then in the final form of the Christian society. It was only when the Christian impulse, with the aid of the Roman tradition of law, had created for the intellectual freedom of Greek speculation a body politic which assured it of an abiding home that science, in the modern sense, became possible. For science lives by a continuous tradition of scientific integrity, created and continually renewed by conscience. The scientific community is the child of the free society."

If Mr. Murry had done no more than direct attention to the new threat to scientific integrity which the spread of Russian communism offers, his book would have deserved attention. Men of science who were alert to the threat which the rise of Nazism and Fascism a decade and a half ago offered to science have sometimes been unhappily blind to the new danger. As Mr. Murry observes, members of the scientific community in the free society are frequently engaged in undermining that free society in the name of science, and there could not well be more alarming evidence of our peril. If the pursuit of research and of learning depends upon a consensus and community of consciences which are obtainable only within the free society, men of science must act in defence of that society.

That defence must be based upon understanding, and it is as a contribution to the clear thinking here required-which is the more imperative if the discrimination referred to in the Prime Minister's statement of March 15 is to be used wisely and without detriment to the democratic tradition or the growth of the free society-that Mr. Murry's book is most welcome. He is indeed challenging and provocative ; and it would be a misfortune if the slightly dramatic character of the book diverted attention from the more fundamental issues which are raised.

What distinguishes the free society from other forms of society, according to Mr. Murry, is the prevalence within it of the fundamental liberties of the subject of freedom of conscience, of speech, of expression and of association. Those liberties are indeed subject to restraints, and he insists that it is by the achievement of tolerance that the free society becomes possible. Nevertheless, he argues cogently that in a world such as exists to-day, a free society can only be established by a government which, believing in the free society, is convinced of the necessity of refusing to tolerate the intolerant, and possesses the power to repress them with evenhanded justice, both on the Right and on the Left.

Mr. Murry thus advances powerful reasons in support of the Government's decision ; but in displaying the tension between the need for the satisfaction of conscience and the need for ordered society which the free society seeks to release, he brings to the front the immense moral issues involved. A free society,

* The Free Society. By John Middleton Murry. Pp. 292. (London : Andrew Dakers, Ltd., 1948.) 128. 6d. net. 
he says, lives by a firm belief that its citizens have the moral energy to correct their own mistakes, and to correct them before serious or irreparable harm is done to the fabric of the free society. It is a question of responsible power, conferred by the democratic process and exercised responsibly with respect to the rights of the minority and also to the welfare of the whole society. The free society, in fact, is a great experiment, and it is above all for his clear indication of the collective and moral responsibility of individuals and groups in Great Britain involved in this affirmation of the dignity, the freedom and responsibility of man that this book deserves to be pondered.

There is first, as Mr. Murry justly observes, room for doubt as to whether the workers appreciate the necessity of dealing justly with one another or with society as a whole. Here his words should be weighed by the trade unions as well as by professional associations in general. Before the free society can be regarded as reasonably secure, the workers must be taught their new responsibilities.

That may well be the most important and urgent task a free society has to undertake; but with it, and of it, must go an increasing consciousness of the whole in existing groups and associations. An ordered society requires discipline; but in a free society that social discipline must be a self-discipline; and here, as Mr. Murry reminds us, is the importance of voluntary groups and associations within the free society. To the degree to which they are inspired by an understanding of the free society, they will establish the patterns of just legislation before the need of legislation becomes acute. They will anticipate the social disciplines which the free society needs.

Now while Mr. Murry pertinently reminds us that in the free society the loyalty demanded is no longer primarily loyalty to the fellow-members of a group or section but to the free society as a whole, it is as well to remember that there is a converse side. The disciplines voluntarily accepted in the free society are disciplines which must be accepted above, by the government, as well as the governed; and they too must be inspired by an understanding of the free society as well as by a vision of its potentialities. To take only one instance at present in the public mind. It would be a grave mistake for the Government to imagine that the uneasiness of a large part of the medical profession over the new Health Act is not due to misgivings as to whether the profession will be able under the Act to give the public service which its professional ideals and traditions require it to render.

In dealing with the danger to the State of communist activities, a profound saying of Burke may be recalled: "It is no inconsiderable part of statesmanship to know how much of an evil ought to be tolerated". The Government has rightly decided that democratic principles do not call for the toleration of treason and terror, and it has wisely left it to the community to decide on the larger and fundamental issue, whether, in a democratic society, free scope should be given to those who seek to destroy democracy and to set up an intolerant regime.
If, therefore, the Government, in administering the decision, makes sure that impartial justice is done where the person concerned is not a member of the Communist Party but charged with "continuing association with it", it may well be claimed to have met Burke's test of statesmanship. That will not indeed avert the need for constant vigilance within and without Parliament. The debate on March 25 should have reassured those who fear that the cloak of security may be used to stifle the integrity of science and the ability of the scientific worker to serve mankind. But it is for scientific workers individually and in their professional associations to take up the challenge to fundamental thinking and constructive action which Mr. Murry throws down to them in "The Free Society" ; in that way only can freedom be ultimately safeguarded in science or among the free nations of the world.

\section{FAMILY AND NATION}

$T$ HE broadsheet series entitled Planning issued from time to time by P.E.P. (Political and Economic Planning) has produced many excellent and stimulating documents, and has made a valuable contribution to the solution of several of the social and economic problems with which Britain has been and still is confronted. The latest issue, entitled "Family and Nation", is, however, frankly disappointing. Much of the information in it is of great interest, and it raises many important issues which need to be raised and to be raised frequently. Admittedly the family is difficult to plan for, being so variable and so individual; and there is unconscious or perhaps conscious humour in the statement that it "must be strengthened in the functions for which it is peculiarly suited, such as the production of children". After an excellent section reviewing the fluctuation in the birth-rate, the introduction of family allowances, and the present state of incometax rebates, the broadsheet goes on to outline a plan whereby the 'para-medical' services, together with marriage guidance, can all be combined in a family welfare service.

Such a proposal needs the most careful consideration at the present time, for it presupposes a large expenditure of public money and it also cuts across the recommendations of the Denning Committee ${ }^{1}$. Both are serious matters, and one would therefore expect weighty reasons to be given in support of the proposal.

The functions of the proposed new organisation would be to "improve the conditions in which children grow up, increase the number of 'wanted' children and help to reduce the number of ehildren whose birth is not desired either by their parents or by the community ..." This is a wide programme involving many issues, some highly controversial ; but the broadsheet suggests that "the existing arrangements for maternity and child welfare would provide a foundation" for implementing it, "other provisions being added as they were shown to be desirable and practical". But suppose for the sake of argument that the controversial difficulties had been surmounted 